\title{
Study on the Histological Changes in the Parenchyma of the Placentae of Preeclamptic Women
}

\author{
SEGUPTA KISHWARA ${ }^{1}$, ABU SADAT MOHAMMAD NURUNNABI ${ }^{2}$, DIPALI RANI PAL ${ }^{3}$, SHAMIM ARA $^{4}$.
}

\begin{abstract}
:
Context: The histological changes in internal components of the placenta are evident in different maternal diseases like preeclampsia. Postnatal examination of the placenta is an important method for assessing pathophysiological changes as well as maternal and fetal condition in antenatal and perinatal periods and enriching practical knowledge.
\end{abstract}

Study design: Cross-sectional, descriptive type.

Place and period of study: Department of Anatomy, Dhaka Medical College, Dhaka from August 2005 to June 2006.

\begin{abstract}
Materials \& Methods: 60 human placentae from Bangladeshi women were collected from the Department of Obstetrics \& Gynaecology of Dhaka Medical College Hospital, Dhaka and Sir Salimullah Medical College Hospital, Dhaka, of which 30 from normal uncomplicated pregnancies (control group) and another 30 from pregnancies complicated by preeclampsia (study group), where the patients were normotensive previously.
\end{abstract}

Results: A reduction in the proportional volume peripheral villi and an increase in that of stem villi were found in the placentae of the preeclamptic women $(P<0.001)$, but no change was seen in the volume of total chorionic villi and intervillous space $(P>0.50)$. Moreover, there was an increased fibrinoid deposition in the placentae of the preeclamptic women $(P<0.01)$.

Key words: placenta, preeclampsia, parenchyma, chorionic villi, intervillous space, fibrinoid deposition.

\section{Introduction:}

The placenta is an organ that is absolutely essential to the survival of the foetus of mammals. Its metabolic functions are complex and it undergoes continuous changes in weight, structure, shape and function throughout the gestation in order to support the prenatal life ${ }^{1}$. Preeclampsia was first described over 100 years $^{2}$. It is a disease of placenta because it has also been described in pregnancies where there is trophoblast but no foetal tissue. The most prevalent characteristics of preeclampsia are ischemic changes and amnionitis ${ }^{3}$. The pathophysiological changes in internal components of the placenta are evident in preeclampsia and eclampsia, where the uteroplacental ischaemia is held responsible for most of the placental changes ${ }^{4}$. Along with the morphological changes, marked changes are also found in the parenchymal structures of the placenta. The definitive pathogenesis of these structural abnormalities, their correlation with placental function, and their relationship to perinatal morbidity and mortality in these high-risk pregnancies are still to explore ${ }^{5}$. The aim of the present study is to see the range of alteration in different components of the parenchyma of the placentae of preeclamptic mothers in comparison to normal pregnancies. Microscopically, the chorionic villi (i.e. peripheral and stem villi) and the intervillous space were included in the parenchyma ${ }^{6}$. The stem villi can be distinguished from the peripheral villi by their large size and presence of arterioles and venules, but fewer capillaries, and considerable amount of connective tissue stroma with fibroblasts associated with a decreased number of trophoblast cells on their periphery. The terminal or peripheral villi are small, rounded or oval contain numerous fetal capillaries and fibroblasts in a collagenous stroma and are lined by continuous

1. Assistant Professor, Department of Anatomy, Dhaka Medical College, Dhaka.

2. M.Phil. student, Department of Anatomy, Dhaka Medical College, Dhaka.

3. Associate Professor, Department of Anatomy, Jahurul Islam Medical College, Bajitpur, Kishoreganj.

4. Professor and Head, Department of Anatomy, Dhaka Medical College, Dhaka. 
syncytiotrophoblast layer ${ }^{7}$. There are also some fibrinoid depositions. The findings are expected to increase the information pool on internal changes of the placenta, and thereby, help the clinicians and researchers to understand more on preeclampsia and eclampsia, especially in the developing countries like Bangladesh, where the vulnerability is very high.

\section{Materials \& Methods:}

A cross-sectional descriptive study was carried out in the Department of Anatomy, Dhaka Medical College, Dhaka from August 2005 to June 2006 on 60 human placentae from Bangladeshi women, of which 30 collected from normal uncomplicated pregnancies (considered as control group) and another 30 from pregnancies complicated by preeclampsia (considered as study group) where the patients were normotensive previously. The placentae were collected from pregnant women whose deliveries (either normal vaginal delivery or Caesarean section) were conducted in the Department of Obstetrics \& Gynaecology, Dhaka Medical College Hospital, Dhaka and Sir Salimullah Medical College Hospital, Dhaka. Pregnant women were selected between 35-40 weeks of gestation. Selection of the control and the study group was done on the basis of diagnosis by a registered physician or from the hospital record. Each of the placentae was collected in a labeled plastic bag within 6 hours of delivery.

\section{Procedure of the microscopic study:}

A. Selection of the tissue: From each placenta two tissue blocks were taken for microscopic examination, one from central and other from peripheral portion of a placenta with a measurement of about $1 \mathrm{~cm} \times 1 \mathrm{~cm} \times 0.5 \mathrm{~cm}$. Tissue blocks were taken from the central portion of a cotyledon, which was sectioned in a plane parallel with the maternal and fetal surface. All the tissue blocks were taken from the area which appeared normal and or least pathologic to prepare better slides ${ }^{7}$.

B. Preparation of the slide: Tissue blocks were nixed in $10 \%$ normol saline in a plastic container. The tissues were washed in running tap water, dehydration was done with ascending grades of alcohol, cleared with xyline infiltrated and embedded in paraffin. Paraffin blocks were cut at
$6 \mu \mathrm{m}$ thickness and were stained with routine Harris' Haematoxylin and Eosin (H\&E) stain.

C. Estimation of the proportional volumes of the histological components: The proportion of volume of chorionic villi (i.e. peripheral and stem villi), the intervillous space and fibrinoid deposition were determined with the point counting Zeiss I integrating eyepiece prepared in a transparent plastic sheet and was placed into the eyepiece. The integrating eyepiece contains a point network of 25 points, spaced at $70 \mu \mathrm{m}$, arranged within a circle which delimits the counting field 6 . The counting was done under light microscope (Olympus CHB, made in Japan) at high magnification ( $\times 40$ objective $\times 10$ eyepieces), following Laurini and Visser $(1987)^{8}$ in slides stained with routine H\&E stain. The position of each point of eyepiece falling on any component of the placenta i.e. stem or peripheral villous, intervillous space and fibrinoid deposit (Fig.1) was recorded for each field. Then the eyepiece was rotated $90^{\circ}$ keeping the field constant. Again the position of the each point was recorded. Thus 50 points were recorded for each field. 10 such fields or 500 points were studied on each section, As 2 blocks were prepared from each placenta, a total of $500 \times 2$ i.e. 1000 point positions were recorded for each placenta. The total number of points hitting each components of parenchyma was summed up and expressed as a percentage. This percentage represents the proportional volume of the different components of the parenchyma of the placenta ${ }^{6}$.

\section{Statistical processing of data:}

The collected data were processed and statistical analyses were done by unpaired Student's 't' test. All the statistical analyses were done by using the SPSS 11.0 version.

\section{Results:}

There was a significant reduction in peripheral villi and increase in stem villi in the placentae of the preeclamptic women $(P<0.001)$, but no change was seen in the percentage of total villi and intervillous space $(P>0.50)$ (Table-I). Moreover, there was an increased fibrinoid deposition in the placentae of the preeclamptic women $(\mathrm{P}<0.01)$ (Table-I). 
Table-I

Comparison of proportional volume of components of placental parenchyma and total villous volume between the two study groups

\begin{tabular}{|c|c|c|c|}
\hline Variables & $\begin{array}{c}\text { GroupA } \\
(n=30) \\
\text { Mean } \pm \text { SD }\end{array}$ & $\begin{array}{c}\text { Group B } \\
(n=30) \\
\text { Mean } \pm S D\end{array}$ & $P$ value \\
\hline Peripheral & $61.00 \pm 4.20$ & $54.29 \pm 4.70$ & $<0.001^{\star \star \star}$ \\
\hline villi (\%) & $(49.0070 .00)$ & (46.80 72.00) & \\
\hline Stem villi (\%) & $\begin{array}{c}9.52 \pm 2.66 \\
(3.2017 .00)\end{array}$ & $\begin{array}{l}15.92 \pm 3.24 \\
(4.202 .60)\end{array}$ & $<0.001^{\star \star *}$ \\
\hline $\begin{array}{l}\text { Intervillous } \\
\text { space (\%) }\end{array}$ & $\begin{array}{c}27.33 \pm 2.00 \\
(25.0033 .00)\end{array}$ & $\begin{array}{c}27.16 \pm 2.48 \\
(20.0030 .00)\end{array}$ & $>0.50 n s$ \\
\hline $\begin{array}{l}\text { Fibrinoid } \\
\text { deposition (\%) }\end{array}$ & $\begin{array}{c}2.16 \pm 0.68 \\
(1.204 .00)\end{array}$ & $\begin{array}{l}2.62 \pm 0.53 \\
(1.303 .40)\end{array}$ & $<0.01^{\star \star}$ \\
\hline $\begin{array}{l}\text { Total volume of } \\
\text { Chorionic villi (\%) }\end{array}$ & $\begin{array}{c}70.52 \pm 2.40 \\
(64.0073 .00)\end{array}$ & $\begin{array}{c}70.21 \pm 2.82 \\
(67.0078 .20)\end{array}$ & $>0.50 \mathrm{~ns}$ \\
\hline
\end{tabular}

Group A : Control

Group B : Preeclampsia

Figures in parentheses indicate range. Statistical analysis done by unpaired Student's 't' test, ns = not significant, $\star \star / \star \star \star * ~ s i g n i f i c a n t$.

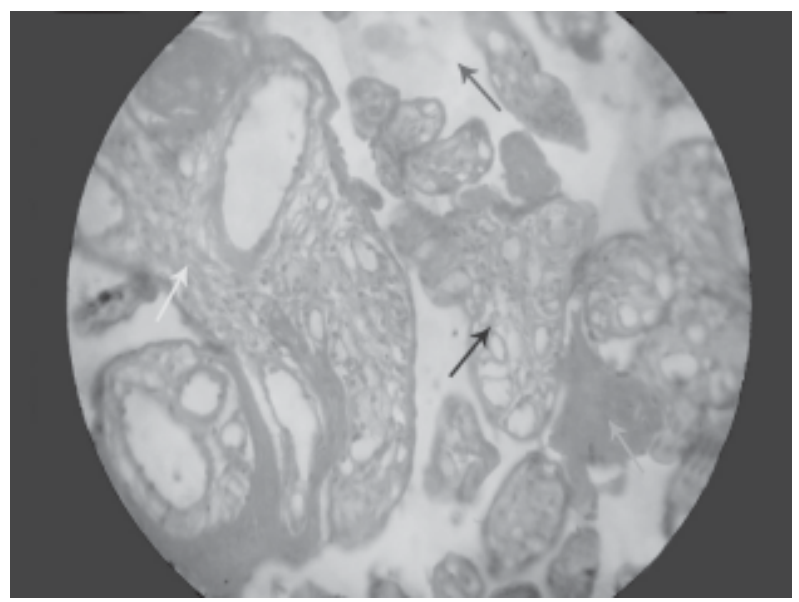

Fig.-1: Photomicrograph of a section of a placenta showing components of the parenchyma; terminal villi (blue arrow), stem villi (yellow arrow), intervillous space (red arrow) and fibrin deposition (green arrow), seen under the light microscope $(\times 40$ objective $\times 10$ eyepiece) ( $H$ \& E stain).

\section{Discussion:}

Teasdale $(1987)^{9}$ found that the volume of placenta was significantly decreased in preeclamptic mothers and there was a reduction of parenchymal tissue due to significant reduction in peripheral villi, fetal capillaries and intervillous space volume. All parenchymal tissue components i.e. intervillous space, peripheral villi, trophoblast and capillaries, were decreased by approximately $50 \%$ in the placentae of preeclamptic mothers. Despite of $52 \%$ reduction in the mass of peripheral villous tissue, the stem villous tissue was shown to be increased in the placentae of the mother with growth retarded foetus. Intervillous space volume was significantly reduced in relation to the total villous tissue volume. There was proportionally more stem and less peripheral villous tissues in the placentae of the preeclmptic compared to the controls. According to Boyd and Scott $(1986)^{10}$, the placentae from women suffering from preeclampsia and from those giving births to small-for-dates' (SFD) babies consistently have a smaller volume of the parenchyma as well as the total volume and more have areas of multiple infarctions when compared with placentae from uncomplicated pregnancies. Conversely, those placentae from patients with hypertension uncomplicated by preeclampsia have a similar or higher volume of the parenchyma than those of uncomplicated pregnancy. Jones and Fox (1980) ${ }^{11}$ suggested that some of the placental changes in preeclampsia could represent the compensatory mechanism in the placenta e.g. an increase in stem villous volume, marked reduction of total villous volume and intervillous space volume etc. which are helpful to some extent to overcome the unfavourable maternal environment, in spite of the reduction in its volume. Aherne and Dunnill (1966) ${ }^{12}$ found that in the control group, the mean placental volume of non-parenchyma amounted to $21.9 \pm 3.4 \%$. In the parenchyma, the volume proportion of chorionic tissue was $59.5 \pm 3.2 \%$ and of intervillous space $37.3 \pm 3.2 \%$. In placentae from hypertensive pregnancies, the mean value for the volume proportions of chorionic tissue and intervillous space were $58.9 \pm 5.7 \%$ and $38.7 \pm 5.7 \%$ respectively; these did not differ from the corresponding normal values. According to them, in hypertensive pregnancies the maternal intervillous pool was reduced to $74 \%$. For all types of placenta the volume of the intervillous space is reduced slightly by the deposition of 'fibrin'12. In the present study, though the fibrin deposition was significantly increased, the intervillous space volume remained unchanged. Moreover, the determined volume of the intervillous space in preeclamptic cases was much lower than that of Aherne and Dunnill (1966). However, the peripheral villi were found to decrease by only $10 \%$, which was 
much lower than that of Teasdale (1987) and Boyd and Scott (1986), and the stem villi increased by $60 \%$ in the placentae of the preeclamptic women, which was similar to the findings of Jones and Fox (1980), but much higher than that of Teasdale (1987). Unlike the findings of the previous studies, no changes were found in total villi and intervillous space in the placentae of the preeclamptic women in the present study.

\section{Conclusion:}

This histological alteration in the placenta due to preeclampsia contributes to the high mortality and morbidity of both mothers and neonates in our country. The underlying pathophysiology is still to be explored a lot. Hence, further studies with larger samples and high technical back up are recommended. Besides, proper antenatal screening and care should be ensured in all maternal and child healthcare institutes and organizations.

\section{References:}

1. Teasdale F. Gestational changes in the functional structure of the human placenta in relation to fetal growth: a morphometric study. Am J Obstet Gynecol. 1980; 137: 560-3.

2. Kalra VB, Agarwal A, Sareen PM, Kalra R. Histopathological Changes in placenta in toxaemia of pregnancy. J Obs Gynae India 1985; 35: 86-90.

3. Cortes $\mathrm{H}$, Munoz $\mathrm{H}$. The clinical usefulness of a histopathological study of the placenta at San Vicente de Paul Teaching Hospital. [Aticle in Spanish] [Abstract]. Rev Colomb Obstet Ginecol. 2007; 58(1): 60-4.

4. Fox $\mathrm{H}$ and Jones CJP. Pathology of trophoblast. In: Loke YW and White A. eds. Biology of trophoblast. $3^{\text {rd }}$ ed. New York: Elsevier; 1983. p.137-85.

5. Fox $\mathrm{H}$. The placenta in maternal disorders. In: Bennington JL. ed. Pathology of the placenta. $2^{\text {nd }}$ ed. Philadelphia: W. B. Saunders; 1978. p.213-37.

6. Laga EM, Driscoll SG, Munro HN. Quantitative studies of human placenta. I.Morphometry. Biol Neonate. 1973; 23: 231-59.

7. Wong T, Latour JPA. Microscopic measurement of the placental components in an attempt to assess the malnourished newborn infant. Am J Obstet Gynecol. 1966; 94(7): 942-50.

8. Laurini RN, Visser GHA. Morphological findings in placenta of insulin dependent diabetic patients treated with continuous subcutaneous insulin infusion. Placenta. 1987; 8: 153-65.

9. Teasdale F. Histomorphometry of the human placenta in preeclampsia, associated with severe intrauterine growth retardation. Placenta. 1987; 8: 119-28.

10. Boyd PA, ScottA. Quantitative structural studies on human placentas associated with preeclampsia, essential hypertension and intrauterine growth retardation. $\mathrm{Br} \mathrm{J}$ Obstet Gynaecol. 1985; 92: 714-21.

11. Jones CJP, Fox H. An ultrastructural and ultrahistochemical study of the human placenta in maternal preeclampsia. Placenta. 1980; 1: 6176.

12. Aherne W, Dunnill MS. Quantitative aspects of placental structure. J Pathol Bacteriol. 1966; 91: 123-39. 